\title{
Scientific Development and Domestic Demand $\left(2003^{-2011)}\right.$
}

\section{Introduction}

In the initial period of reforms, China's economy experienced rapid growth. However, the amalgamation of centralized bureaucratic administration and market regulation induced excessive demands for investment and unproductive use of capital. As a result, the pattern of development was markedly volatile. Periods of rapid growth were persistently accompanied by inflation and were therefore generally succeeded by the reinstatement of central controls on capital. After some 15 years of oscillating between conservative and progressive templates, by the end of the 1990s Chinese leadership appeared to have formulated an alternative mode of economic governance that finally achieved the long-pursued twin objectives of rapid development and macroeconomic stability. The consolidation of central control over credit in the mid-1990s hardened budget constraints for local government and enterprise, and the privatization of small enterprise greatly reduced the strain of insolvent public industry. Even when the financial crisis of 1997 swept across the Asian continent, causing widespread stagnation, the Chinese economy remained relatively unscathed, and under Jiang and Zhu, the economy continued to grow at a rapid rate. ${ }^{198}$ The economic fortitude of the central state grew in tandem with overall economic development. The 1994 tax reforms had led to a rapid increase of central revenues, and the reorganization of state-owned industrial assets in large conglomerates consolidated central control over China's major upstream industries.

Notwithstanding these economic achievements, pressure for additional reforms mounted. In its pursuit of rapid economic growth, the state had neglected distributive issues. High returns had caused government funds and foreign investment to flow to the modern coastal economy of the eastern provinces. This investment bias stymied development of China's interior, which

198 Amongst the factors contributing to China's insulation from the Asian financial crisis were the constraints on cross-border capital and currency transactions, curbing the outflow of domestic capital, the predominance of FDI over short-term foreign-invested capital, and the reduction of the scale of non-performing loans (Wang 1999; Yu 2007). 
had remained strongly dependent on agriculture and outdated industry. The marked divergence in regional development was accompanied by a widening gap between cities and countryside. Whereas the rural economy had been invigorated by the introduction of TVEs, much of this progress was undone by the reforms of the mid-199os. The redistribution of fiscal revenues had disproportionately shifted burdens to subnational levels of government. Attempts by local government to compensate for the loss of revenue caused extrabudgetary levies on peasants to proliferate. Moreover, due to the local privatization drive that emerged in the wake of fiscal reforms, a large portion of TVEs had been disbanded. The destabilizing consequences of growing inequality became a prominent subject of debate under of President Hu Jintao and Prime Minister Wen Jiabao. Subsequently, central leadership would emphasize that development needed to promote both growth and social stability (shehui hexie, Hu 2007). The shift in central economic discourse from single-minded pursuit of rapid growth to more equitable development was accompanied with significant apprehension about the long-term implications of capital-dependent development. Jointly, societal and strategic concerns caused a widespread perception that a fundamental transformation of the mode of economic development (jingjifazhan fangshizhuanbian) was required, prompting Hu to formulate his "scientific development concept" (kexue fazhan guan).

However, in the first decade of the 21st century, the rate of accumulation increased and progress in dealing with issues of rural underdevelopment and interregional disparity was slow. The failure of scientific development to realize a fundamental readjustment in the dynamics of growth was due to the manner in which attempts to deal with sustainability and inequality were framed within the context of the more immediate problem of stimulating domestic demand. While the departure from economic policy biased toward urban, heavy industry, in favor of a focus on rural development and the promotion of technology-intensive sectors, did expand consumption, its major effect was to intensify accumulation by providing new conduits for investment. In spite of the emphasis of economic discourse on readjustment and sustainability, economic development remained strongly dependent on the continuous expansion of fixed capital.

\section{Distributive Concerns and the Dynamics of Growth}

The scientific development concept, promulgated by Hu Jintao in May 2004 seemed to indicate another turning point in China's economic development. After some three decades of rapid growth the inherent limitations of 
capital-intensive development had become increasingly salient. Labor had remained largely of the unskilled variety. The backward state of China's inland regions provided a stark contrast with the rapid modernization of the coastal areas. Urban-rural imbalances continued to exacerbate and were compounded by social aggravations resultant from the abolishment of the employment guarantee and retrenchment of the public sector. These developments had convinced several scholars and policymakers in the mid-199os (such as Hong Yinxing of Nanking University, economist and NPC member Song Zexing, and Zhou Zhenhua of the Shanghai Academy of Sciences) that China needed to depart from its established pattern of extensive (cufangxing) accumulation. ${ }^{199}$ However, the dominant perspective among central leadership in the mid1990 s was that the brunt of adverse effects of economic development could be addressed through the elimination of inefficient industrial capacity. 200

The scientific development concept represented the attempt by Jiang's successor, Hu Jintao, to comprehensively conceptualize the relationship between the long-standing issues of development, socioeconomic equality and long-term sustainability. However, notwithstanding Hu's efforts to tout scientific development as a seminal extension of the Party's economic discourse, it offered little in the way of truly novel approaches to the problems of worsening inequality and overreliance on the accumulation of fixed capital. As we will discuss below, many of the core elements of Hu's new policy paradigm were actually developed during the tenure of Jiang and Zhu.

\section{Readjustment Revisited: Western Development, Urbanization and the Revitalization of Agriculture}

Although the rapid expansion of the rural economy in the initial period of reforms had caused rural and urban income levels to converge somewhat, these advances toward greater socioeconomic equality were reversed by the subsequent reemphasis of industrial development. From the 1980 os onward, distributive concerns took a backseat to the objective of economic growth. The initial widening of income differentials was regarded as a natural attendant phenomenon of such growth. Nor was this believed to necessarily impel social instability; while certain people would "get rich first" (xianfu) by capitalizing on their novel economic freedoms, the expansion of market relations would eventually ensure equality of opportunity for all Chinese citizens. Up until the latter half

\footnotetext{
199 Hong (1997); Song (1996); Zhou (1996). Also see "Guomin jingji he shehui fazhan jiu wu jihua he 2010 nian yuanjing mubiao gangyao" (1996, ch. 2).

200 "Guomin jingji he shehui fazhan jiu wu jihua he 2010 nian yuanjing mubiao gangyao" (1996).
} 
of the 1990s, the prevailing opinion among central leadership was that "[destabilizing income disparity] was not directly brought about by government policy, but rather the outcome of a small minority who was contravening the law by exploiting regulatory loopholes" (Jiang 1989). Accordingly, the main social imperative of government consisted of the eradication of arbitrary regulatory distortions of the relationship between productivity and income.

This laissez-faire approach to the distribution changed from the mid-199os onward. Both within academic and policy debate, a majority came to believe increasing inequalities caused serious socioeconomic polarization (liangji fenhua). In an address to the Leading Group for Finance and Economics (zhongyang caijing lingdao xiaozu) in August 1996, President Jiang opined:

The experience of certain developing nations has proven that an excessively unequal distribution of individual and regional distribution of income will prompt contradictions within society, amongst regions and classes, between the centre and locality, and cause great disorder. Therefore, the problem of increasing income and inter-regional inequality must attract our greatest attention. We must persist in the policy of allowing the initial enrichment of a portion of people and areas, so that they can bring about and aid the enrichment of those who are not yet affluent, so as to gradually realize mutual welfare. At the same time, we must turn the adjustment of individual incomes, and reduction of regional economic divergences into a major task relating to our overall situation, so as to grasp and sincerely address the various social relations and contradictions within economic development.

1996

Jiang's statement amounted to an implicit recognition that the objective of realizing ubiquitous welfare could not be realized by means of a "trickle-down" effect only, and additional state intervention was necessary to maintain social stability. $^{201}$

Among the various explanations proffered for increasing inequalities, the perspective that came to predominate policymaking focused on the economy's

201 This trickle-down effect theoretically ought to ensure that, while rapid accumulation will initially concentrate capital within the hands of a small cohort of economic actors, improvements in productivity will eventually impel a higher standard of living among the general population. In an argument applicable to the Chinese context, Aghion and Bolton (1997) posit that, particularly in the case of constrained capital markets, additional redistribution is necessary to promote a comprehensive rise in welfare. 
dualistic structure (er yuan jingji jiegou). ${ }^{202}$ Despite the agricultural reforms of the late 1970s, a marked difference in incomes continued to exist between agriculture and more productive industry. Moreover, the spatial distribution of agricultural and industrial activity largely coincided with the regional division between inland and coast and the interregional separation of countryside and city. As such, inequalities were largely circumscribed by the geographic delineation between China's interior and eastern provinces and rural and urban areas (Zhao 1992; Zhao and Li 1992). According to Gu Shutang of Nankai University, this spatial-structural economic juxtaposition was ultimately attributable to insufficient population density, precluding the formation of supply-anddemand-side economies of scale (Gu and Tang 1994). Gu's "consolidation thesis" agreed with extant priorities of central leadership. Notably, by emphasizing how inequality posed a bottleneck to further economic growth, an ostensible tradeoff between efficiency and equity could be avoided. Likewise, the center would be able to leverage its consolidated fiscal position to guide the development of industrial hubs within sparsely populated areas, precluding the need for further systemic reform.

Central initiatives to address regional economic inequalities took the form of the Western Development Program (xibu da kaifa). ${ }^{203}$ Having pondered the issue over the course of several years, Jiang proposed the program to central leadership in March 1999. In accordance with contemporary economic debate, the development of the interior regions was not only presented as a pivotal measure in the alleviation of income disparity, but also as a requirement for enduring economic growth. The construction of industrial and civil infrastructure would promote both scale economies in industry and the expansion of underdeveloped consumer markets (Jiang 1999). The following month, ministerial and provincial leadership proceeded to discuss the initiative under the guidance of the State Planning Commission. Unsurprisingly, representatives from the western provinces strongly endorsed the strategy. Yet, others believed the central state lacked both the financial resources and the administrative control necessary to successfully engage in western development. Rather, they advocated a continuing emphasis on investment in the coastal regions (Ceng 2010). Ultimately, Jiang's perspective would prevail. In the wake of the Asian financial crisis of 1997, Zhu Rongji had actively sought to reduce China's dependency on foreign markets, and the development of domestic demand

\footnotetext{
202 See for example Jiang (2001).

203 The Western Development Program targets the provinces of Gansu, Guizhou, Qinghai, Shaanxi, Sichuan and Yunnan, the autonomous regions of Guangxi, Inner Mongolia, Ningxia, Tibet and Xinjiang, and the municipality of Chongqing. See Holbig (2004).
} 
had become a focal point of economic policy (Zhu 1999). This resolve dovetailed with Jiang's drive to exploit the potential market of the interior regions, and the "Decision on Certain Major Issues in the Reform and Development of State-Owned Enterprise" of September 22, 1999, institutionalized central commitment to western development. By 2002, the program encompassed 20 investment projects (mostly related to infrastructure), jointly accounting for over 400 billion yuan (Wallace 2014). ${ }^{204}$

Efforts to deal with the unequal development of city and countryside proceeded in tandem. During the early stages of reform, government had adopted a policy of "controlling the scale of large cities, rationally developing middlesized cities, and actively developing small cities and villages" (kongzhi da chengshi guimo, heli fazhan zhongdeng chengshi, jiji fazhan xiao chengzhen). However, central engagement in developing small cities was, by and large, limited to administrative measures, ${ }^{205}$ introduced in order to curb widespread rural migration. ${ }^{206}$ Control of population movement, notably by way of the household registration system, which tied access to social welfare to residence status, had been considered pivotal to the maintenance of social stability in China's large cities (Wallace 2014). Although the strategy of rural-urban segregation and development of townships had reduced the development of inequalities in China's coastal metropolises by preventing an influx of poor rural migrants, it had likewise prevented the formation of new urban concentrations. The long-term trend toward socioeconomic polarization and the stymied development of domestic demand bolstered Jiang's resolve to expedite urbanization. The construction and expansion of small and medium-sized cities in China's rural areas would provide an outlet for surplus agricultural labor, and promote industrialization. ${ }^{207}$ Trials commenced in April 1995, and in 1998 the strategy of developing urban hubs within the Chinese countryside was elevated to national policy. ${ }^{208}$ As a result, the rate of urbanization in the late 1990s rapidly increased; from 1996 to 2003 the proportion of urban citizens

204 Note, however, that a considerable amount of investment had already commenced prior to the initiation of the program, and was subsequently relabeled as part of western development.

205 In October 1984, the "Circular on the Issue of Farmers' Settlement in Towns" allowed rural citizens enjoying steady employment in TVEs or other industrial enterprise and having fixed residency within towns to convert their rural household registration to a township (chengzhen) residence permit.

206 Note that the sudden increase in townships from 1983 to 1984 observable in government statistics is chiefly due to statistical reclassification.

207 "Zhongguo xiao chengzhen zonghe gaige shidian zhidao yijian" (1995).

208 "Guanyu nongye he nongcun gongzuo ruogan zhongda wenti de jueding" (1998). 
in the total population rose from 30.5 to 40.9 percent, an increase almost equal to that realized in the entire preceding period of reforms (NBS 2013, table 3-1).

While urbanization sought to reduce socioeconomic divergence through the adjustment of the sectoral composition of China's rural economy, other policies focused on the reorganization of agriculture itself. The first of these measures sought to promote the efficiency of agricultural production through industrialization (chanyehua). Within the context of agriculture, industrialization referred to the development of vertically integrated production networks, constituted by an agglomeration of individual producers and controlled by "dragon head enterprises" (longtou qiye, see Yan and Chen 2013). In essence, the policy reiterated the logic of the conglomerate strategy within the public sector, whereby the integration of small producers within vast conglomerates would yield economies of scale and promote specialization on the basis of the different comparative advantages of agricultural regions (Renmin Ribao 1995). After several years of experiments at the municipal level, agricultural industrialization was elevated to national policy in $1998 .^{209}$

In addition to attempts to increase agricultural productivity, the state introduced fiscal policies which sought to directly increase peasant incomes. Trials with so-called "from fee to tax" (feigaishui) reforms commenced in March 2000. Under these reforms, the tax rate on agricultural produce was decreased to 7 percent (calculated on basis of an estimate of 1998 yields), and the various extrabudgetary levies on peasants which had financed public services at the village level were abandoned in favor of a standardized surcharge on agricultural tax. Finally, the practice of compulsory labor for the construction of village infrastructure was abolished. ${ }^{210}$ These reforms, however, proved ineffective in improving peasants' livelihood. Implementation of the new tax scheme was heavily contested by poorer localities, which saw their fiscal base erode as a result of the abolition of extrabudgetary revenues. In a reiteration of the dynamics following the tax reforms of 1994, local administrations increasingly turned to the expropriation of farmland in order to compensate for the loss of income (Day 2013). Ironically, the exploitation of farmers was exacerbated by the urbanization drive, which drove up demand for land (Sargeson 2013). Between 2000 and 2003, real rural consumption expenditure rose by a mere average 3.7 percent (by contrast, urban consumption expenditure in the same period increased by an average 6.1, NBS 2012, table 2-24).

$209 \operatorname{Li}(1998$, ch. 2).

210 "Guanyu jinxing nongcun shuifei gaige shidian gongzuo de tongzhi" (2000). 


\section{From Extensive to Intensive Development: Nurturing the Indigenous Capacity for Innovation}

Introspection about the structural characteristics of China's economic development and its distributive implications was accompanied by a debate on the limitations of its dynamics. ${ }^{211}$ From the latter half of the 1990s onward, both economists and policymakers fervently discussed the transition from extensive to intensive growth. ${ }^{212}$ Extensive accumulation occurs through the continual addition of heretofore unutilized resources and labor (Andreff 1978; Aglietta 2000). By contrast, under intensive (jiyuexing) accumulation, growth occurs primarily because of innovation, that is, through the continuous reorganization of capital and labor into more productive configurations (Lipietz 1988). ${ }^{213}$ Chinese discourse highlighted how both endogenous and exogenous influences mandated an imminent shift toward a predominantly intensive pattern of accumulation. A first such catalyst derived from the dynamic of economic development itself. Due to the predominance of agriculture, backward production technology and a lack of effective domestic demand characteristic for emerging economies, initial development would have to capitalize on the comparatively abundant supply of labor and natural resources. Market expansion would, however, create scope for the development of scale economies, investment in fixed assets and labor specialization. At such a point, the reliance on comparative advantage ought to be decreased in favor of a strategy of developing institutional advantages within specific productive processes (Zhou 1996).

Not only do endogenous dynamics push for the transition toward intensive accumulation, but there are also inherent limits to the continuation of an extensive mode of accumulation. Due to the finiteness of labor and capital and diminishing returns to factor addition, argued Song Zexing, sustainable growth depended ultimately on continual increases in productivity, realized through technological innovation (Song 1996). Within China, the constraints of extensive accumulation were reflected in a high rate of capital formation and

\footnotetext{
211 That is, sectoral and spatial.

212 Although such discussions had commenced in the early 1980s, in his closing address to the fifth plenum of the fourteenth Party congress, Jiang stated that "[We] must revise our conceptualization of development, and realize the transition from an extensive to intensive mode of development." Jiang (1995). See also Li (1995a).

213 Although the terminology derives from Soviet Marxian analysis, the concepts are also widely applied in neoclassical literature. Consider, for example, the seminal Solow model (Solow 1956), which disaggregates the factors of economic production in labor and capital, and technology (where increases in the first two factors impel extensive growth, and the latter condition causes intensive growth).
} 
correspondingly limited increases in consumption. Extensive accumulation also increased environmental degradation (Jiang 1995). ${ }^{214}$ Finally, pressures to realize the transition toward intensive accumulation were compounded by China's integration into the global economy. While, initially, the ample supply of unskilled labor had provided China with a comparative advantage in the production of labor-intensive goods, rising wages caused this advantage to dissipate (Hong 1997).

Differing opinions existed on how to realize such a transition. Noted reformist $\mathrm{Wu}$ Jinglian argued that increases in factor productivity depended first and foremost on efficient market allocation of capital and competition between economic actors. As such, the transition toward intensive accumulation would require further liberalization of factor markets and industries (Wu 1995). However, within the context of the ascending neo-authoritarian paradigm, the solution that was adopted by government suggested an expansion, rather than contraction, of the remit of regulation. The conceptual foundation for the state's attempts to alter the dynamics of production was provided by the literature on national innovation systems (guojia chuangxin tixi). While the literature on national innovation is conceptually diffuse, the variety (Freeman 1987; Lundvall 1992; Edquist 1997) that proliferated in China took its inspiration from the political economic theory of Friedrich List (Freeman 1995). A late 19th-century political economist, List squarely contradicted the liberal perspectives of his British contemporaries by arguing that government planning plays an indispensable role in the development of national technological competence and international competitiveness. Similarly, the associated brand of innovation systems thinking insisted that government coordination is necessary to nurture innovative competences within industry. Building on the experiences of East Asia's developmental regimes, the national innovation systems literature posited that such coordination ought to ensure the development of close ties between the industrial bureaucracy, education and research institutes and enterprise, which promote the introduction of efficiency- and quality-enhancing technology within industry, and gradually impel a sectoral redistribution within the economy from low to high value-added processes.

214 By the end of 1991, after three years of conservative economic governance, the ratio of gross fixed capital formation to GDP had been reduced to 27.9. However, in subsequent years, economic growth had once again been sustained by large-scale investment in gross fixed capital, and by 1995, its ratio had increased to 34.4. This increase had been accompanied by a corresponding decrease in household consumption expenditure from 49.3 to 46.7 percent (calculated from NBS 2005, table 10). 
The concept of the national innovation system was first introduced to China's leadership by way of a report produced by the Chinese Academy of Sciences in December 1997. It argued that, through the establishment or expansion of central programs that supported the development of leading enterprises, research institutes and universities, China ought to pursue breakthroughs in technologies of particular strategic importance to economic development (Chinese Academy of Sciences 1998). The report was enthusiastically received by Jiang, who himself had called for the "invigoration of the nation through science and education" (kejiao xing guo) some years prior (Chen 2002). ${ }^{215}$ The commitment of the center to the development of China's innovation system was reflected by the establishment of the National Leading Group for Science, Technology and Education (guojia keji jiaoyu lingdao xiaozu) in $1998 .{ }^{216}$

In the following Tenth Five Year Plan, the government presented the outlines of a novel strategy for economic development based on a gradual shift from the expansion of capital in traditional industry to the nurturing of a select number of technology-intensive sectors. ${ }^{217}$ Industries such as information and telecommunications, production automation and renewable energy would not only be crucial in increasing overall productivity, but also presented opportunities for the development of a national competitive advantage. Korean and Japanese precedents convinced the government that China could "leapfrog" (kuayueshi fazhan) within such technology-intensive industries through absorption of mature technologies (Cao, Suttmeier and Simon 2009). ${ }^{218}$ According to the concept of technological leapfrogging, developing nations have singular opportunities to achieve or approximate the technological frontier within selected sectors by skipping certain stages within the development trajectory of these technologies. Specifically, such development is possible when requisite knowledge and technology is readily available within international markets, when innovations succeed one another at a rapid pace (resulting in quick commoditization and low costs), and when technological development is science- rather than experience-based (i.e. radical rather than incremental) and innovation is complementary, rather than labor-substituting (Soete 1985; Lin and Zhang 2005).

Jointly, discourse on issues of social redistribution and the transition from extensive to intensive growth suggested a shift away from the traditional,

\footnotetext{
215 "Guanyu jiasu kexue jishu jinbu de jueding" (1996).

216 "Guowuyuan guanyu chengli guojia keji jiaoyu lingdao xiaozu de jueding” (1998).

217 "Guomin jingji he shehui fazhan di shi ge wu nian jihua gangyao" (2001, ch. 4).

218 See also chapter 2 of ibid.
} 
accumulation-centric economic paradigm. However, driven by rapid urbanization and the incessant expansion of industry, ${ }^{219}$ the high rate of formation of fixed capital was sustained throughout the second half of the $1990 .^{220}$ The 11th Five Year Plan, ${ }^{221}$ prepared under the direction of $\mathrm{Hu}$ and Wen, stated that: "Amidst rapid development during the Tenth FYP period, certain prominent issues appeared: the relationship between investment and consumption was unbalanced, part of industry blindly expanded, production capacity was excessive, transformation of the mode of economic development slowed down, energy resources are strained, environmental pollution has exacerbated, the regional development gap and the income gap between certain groups in society has continued to increase, the development of public services is still lagging behind, and the elements inciting social instability are manifold."222

\section{The Scientific Development Concept}

Hu's response to the plethora of social and economic problems came in the form of the scientific development concept. ${ }^{223}$ According to the concept, a scientific appraisal of the dynamics of economic development and their concomitant imbalances demonstrated an objective need to depart from the extant growth-oriented paradigm to people-oriented, comprehensive, coordinated and sustainable development. The notion of taking people as the basis (yiren wei ben) implied an emphasis on the qualitative as well as quantitative dimensions of economic growth. More egalitarian development would not only alleviate mounting social tension but also facilitate the transition toward a pattern of growth less dependent on the continual expansion of capital and driven

219 In the Tenth Five Year Plan period, the real growth rate of investment in urban construction was an average of 22.1 percent, while industry grew by an average 9.8 percent. By comparison, average GDP growth in that period was 8.4 percent (NBS 2013, tables 2-5, 5-7, 10-1).

220 In 2000, the ratio of gross fixed capital formation was virtually identical to that of 1995 at 34.1 percent.

$2212006-2010$.

222 "Guomin jingji he shehui fazhan de shiyi wunian jihua gangyao" (2006).

223 The concept of "harmonious society" was first propagated in the Resolution of the sixteenth Party congress in November 2002, and further elaborated at the fourth plenary session of the sixteenth Central Committee in September 2004. In an important speech by $\mathrm{Hu}$ Jintao from February 2005, but only published in July 2005, the Chinese leader argues that harmonious society is the "foundation for the consolidation of the governing capacity of the party and the realization of its leading role" (Hu 2005). 
by domestic consumption (Hu 2004). The gradual move from heavy industry toward knowledge and technology-intensive sectors would adjust investments toward labor, resulting in higher wages and lower consumption of natural resources. Comprehensive development (quanmian fazhan) sought to ensure an even pace of economic, political, cultural and social reform. Holistic, planned development (tongchou fazhan) of the relation between city and countryside, between regions, between economy and society, between people and environment and between the nurturing of domestic demand and further opening up (wuge tongchou) would ensure harmonious (hexie) growth. Finally, sustainable development (ke chixu fazhan) would, first and foremost, depend on the restructuring of the industrial composition of Chinese economy. The traditional emphasis on heavy industry would have to be abandoned in favor of less resource- and capital-intensive industries characterized by a strong reliance on technology and high-skilled labor (Renmin Ribao 2006).

Surprisingly, one of the earliest and most resounding endorsements of the scientific development concept originated abroad. According to longtime China observer Joshua Cooper Ramo, the emergent form of governance, which he coined the Beijing consensus, constituted a viable challenge to the liberalist template for economic development (Ramo 2004). The Washington consensus - if not in its original conception then in its subsequent prevalent reading - encapsulated the Western neoliberal model of fiscal discipline, the liberalization of factor markets and international trade and investment, and the predominance of private property (Williamson 1993). This model—or at least the variety adopted by Western international institutions (Babb 2013) advocated a development strategy unequivocally focused on the promotion of growth through exploitation of comparative advantage within the international economy. The Beijing consensus was rather based on comprehensive socioeconomic development, the nurturing of advanced technological capacities, and strategic economic and political leverage. Such a paradigm, argued Ramo, was both attuned to the need for more egalitarian and sustainable development within the Chinese economic system and the increased volatility of international markets (2004). ${ }^{224}$ Following its initial promulgation, the Beijing consensus gained considerable traction among China's academics (notably Hu Angang, director of the Qinghua Center for Research of the National State of China (Zhongguo guoqing yanjiu zhongxin)), and ideologically-oriented publications such as Contemporary World and Socialism (Dangdai shijie yu shehui zhuyi) in particular actively propagated the concept.

224 See Halper (2010) on the international implications of the Beijing consensus. 
However, in spite of the assertions of advocates of the Beijing consensus, the promulgation of the scientific development concept did not portend the emergence of a truly novel economic paradigm. While Hu's contribution to the ever-expanding repertoire of Party ideology seemed to signal that central policy would become less focused on accumulation and egalitarian development had become the overriding priority, ${ }^{225}$ both in terms of ideology and concrete policies, scientific development offered little substantive novelty. The notion of comprehensive development recapitulated Jiang's three represents, which had called for the development of the advanced productive forces (xianjin shengchanli de fazhan) and advanced culture (xianjin wenhua), and the Party's unequivocal pursuit of the interest of the majority of people (zui guangda renmin de genben liyi, Jiang 2001). ${ }^{226}$ Holistic planned development reiterated 5 of the 12 "major relations" (zhongda guanxi) which Jiang had emphasized during the fifth plenum of the fourteenth Party congress. ${ }^{227}$ Likewise, the discussion on sustainable development primarily echoed the economic debate on the transition toward intensive accumulation that had commenced in the mid-199os.

\section{Developing Domestic Demand, Constructing a New Countryside and the Advantage of Large Nations: Theory and Policy under Jiang and $\mathrm{Hu}$}

Given its derivative character and ostensibly limited stature in political and economic discourse, ${ }^{228}$ it would seem straightforward to conclude that the concept of scientific development concept did not influence economic

225 Officially, this repertoire comprises Marxism-Leninism, Mao Zedong thought (Mao Zedong sixiang), Deng Xiaoping theory (Deng Xiaoping lilun) and Jiang Zemin's three represents (san ge daibiao).

226 The rather arcane formulation of the three represents in fact refers to Jiang's endorsement of China's emerging entrepreneurial constituency (i.e. the advanced productive forces), the development of education and higher education in particular (i.e. advanced culture), and attempts to increase intra-Party democracy and combat corruption (i.e. the interests of the popular majority).

227 Besides the five aforementioned relations, these included the relations between reform, development and stability; the speed and efficiency of growth; the sectors of the economy; market allocation and macroeconomic control; the public and non-public economy; center and localities; and military and economic development; see Jiang (1995).

228 Under Hu's presidency, the concept of scientific development received but little attention in leading economic publications. Similarly, an initiative to include the concept into China's Constitution in 2008-ensuring equivalent status with the ideological contributions of earlier leaders - was eventually abandoned. 
development in any material manner. The main consequence of the discourse of scientific development was neither a shift in the stipulated priorities nor instruments of economic governance, but rather to bring about the inherent association of egalitarian and sustainable development with the issue of expanding domestic demand. Discussions on the issue of domestic demand had preceded the formulation of the scientific development concept by several years. The predominant streams of thought advocated a strategy of increasing Chinese consumption and investment through the establishment of new markets.

The first of these streams of thought addressed the inherent limitations of a strategy of economic development focused on heavy industry. While high rates of fixed capital formation within industry had continually exerted a constraining influence on increases in household consumption expenditure (HCE), growth of the latter had been particularly lackluster in the second half of the 1990s. Due to the decline in economic growth brought about by the Asian financial crisis, expansion of domestic demand had become an explicit guideline in national economic policy from 1999 onward. However, in the immediate aftermath of the crisis, state investment targeted the traditional foci of public industry and capital construction. ${ }^{229}$ However, the effect of these stimuli was limited. Lack of consumption expenditure was accompanied by a decrease of investment demand as the depletive effects of structural industrial overcapacity were intensified by reduced domestic consumption and dwindling exports. Lin Yifu argued that, given the inefficacy of direct government investment and limited contribution and scope for increasing exports, resultant deflationary pressure was to be diffused by the exploitation of latent rural demand (Lin 1999). HCE in China's rural areas had been constrained by a lack of requisite infrastructure. The construction of electricity, water and road networks in China's rural villages would not only result in an instantaneous upsurge in demand for major household appliances such as washing machines, refrigerators, televisions and automobiles, but also create additional employment opportunities for the rural working population (Lin 2000).

The second stream of thought expounded on the characteristics and advantages of large economies (da guo jingji). Emerging in the context of growing apprehensions about the benefits of unmitigated international economic integration, the large economy debate asserted that the state could exploit China's

229 In 1998, economic stimuli resulted in a 100-billion-yuan increase in public debt. The majority of investments targeted capital construction. In addition, soes' investment in fixed assets increased by 19.5 percent (compared to an average national increase of 14.1 percent). See Zhu (1999, ch. 1). 
size to expedite development and promote its international competitiveness. Influential economists such as Hu Angang proposed that the establishment of new industries and services and urbanization would promote the expansion of domestic demand, providing new impetus to economic development and decreasing dependence on global markets (Hu 1998; see also Zhang 2001; Chen 2002).230 Through the agglomeration of newly established industrial capital and concentration of the population in urban hubs, such a strategy would also promote the development of scale economies and labor specialization. At the same time, by leveraging domestic demand and its concomitant supply-side advantages, large nations would have singular potential to compete on international product markets.

\section{Scientific Development and the Keynesian Guise of the Chinese State}

Although the notions of exploiting the latent demand of the countryside and the nurturing of novel industries would stipulate the course of economic policy in the first decade of the new millennium, their influence was not immediate. As stated previously, initial attempts by the state to reinvigorate the sluggish economy amounted simply to an increase of expenditure within the traditional focal areas of the producer goods industry and industrial infrastructure. Such measures, however, exacerbated the problem of structural overcapacity and thus did little to increase domestic demand. ${ }^{231}$ The following years saw the substitution of consumption-oriented measures for the initial investment-centered stimuli. The government's 2002 work report insisted that the expansion of demand "first and foremost required the increase of urban and rural incomes, and that of low income groups in particular, so as to nurture and increase household purchasing power" (Zhu 2002). Wages in public industry were adjusted upward, and state expenditure on social welfare increased..$^{232}$ In addition, the government introduced the "from fee to tax" reforms within the rural economy. Although fiscal redistribution did indeed result in an increase of incomes, this did not translate into a commensurate rebalancing of

230 It was further argued that on the supply side, the exploitation of potential domestic demand would promote the development of scale economies and labor specialization.

231 Boyer (2012) argues that the destabilizing effect of this structural overcapacity has been reduced predominantly by way of export. However, due to the crisis-induced slump of demand within international markets, export contracted, increasing the strain of overcapacity on the Chinese economy.

232 Between 1999 and 2002, state expenditure on social welfare increased from 1.34 percent to 2.19 percent of GDP (NBS 2013, tables 2-1, 9-1). 
investment and consumption. Despite tax reforms, urban and rural wages continued to grow at divergent rates, ${ }^{233}$ and in the face of higher uncertainty about employment tenure and increased personal expenditure for welfare services, the propensity to defer current consumption persisted (Chamon, Liu and Prasad 2010). On the supply side, increases in consumption continued to be constrained by the concentration of investment in industries already characterized by excess capacity.

As a result of these persistent problems, the notion of restructuring the composition of domestic capital gained increasing traction amongst Chinese leaders. In 2001, Justin Yifu Lin, director of the Research Center for the Chinese Economy at Peking University, wrote a direct appeal to President Jiang, reiterating his position that both the industrial surplus and excessive supply of industrial investment ought to be addressed by reallocating investment to China's countryside (Wen 2010). The topic of "establishing of a new socialist countryside" (xin shehui zhuyi nongcun jianshe) was discussed during a dedicated conference held in Beijing the following year (Yan and Chen 2013). The government's work report, issued in 2003 , for the first time emphasized how efforts to stimulate domestic demand ought to expedite both the convergence of incomes and industrial restructuring (Zhu 2003). However, it wasn't until the transfer of leadership from Jiang and Zhu to Hu and Wen that these measures were put front and center of economic policy. In 2004, Hu decided to proceed with a progressive reduction of agricultural tax, leading to its complete annulment in 2006 ( $\mathrm{Hu}$ 2004). In order to prevent further erosion of the fiscal position of local government, these changes were accompanied by an increase of fiscal transfers from the center. In 2005, central leadership determined that central outlays for the development of the countryside should increase on a year-by-year basis. ${ }^{234}$ Central outlays for the improvement of rural welfare during the period of the 11th Five Year Plan totaled 2,39 trillion yuan (Wen 2006-2010). ${ }^{235}$ From 2003 to 2010, investment in agricultural development

233 In fact, urban residents had enjoyed tax exemptions for the first 9,6oo yuan of income, whereas rural incomes had been taxed on the full amount (Wallace 2014).

234 "Guanyu tuijin shehui zhuyi xin nongcun jianshe de ruogan yijian" (2005, ch. 1).

235 Before the beginning of the economic reform period, five-year plans were mandatory and set detailed production targets. During the 1980 os and 199os five-year plans increasingly only served as a framework for policies or as a catalogue of issues that needed to be addressed. The Eleventh Five Year Plan reflected this development by calling the plan "guihua" rather than "jihua." While both can be rendered plan in English, "guihua" has a connotation of a draft or regulatory guidelines subject to possible revision, whereas "jihua" often refers to a set of concrete plans. 
grew from 4.6 to 9.1 percent of total state expenditure (NBS 2004; 2011, table 8-5). ${ }^{236}$ Driven by these fiscal transfers to agriculture, rural incomes rose rapidly after $2006 .^{237}$ The increase in rural incomes in turn contributed to the growth of HCE.

Notwithstanding the impetus to consumer demand provided by agricultural transfers, growth under Hu continued to be predominantly (and progressively) driven by investment in fixed assets. Although the concept of a new socialist countryside was broader in substantive scope than preceding programs, urbanization continued to stand firmly at the core of rural development. Urban investment in fixed assets reached an average real growth rate of 26.8 percent in the same period, pushing the urban share of total investment in fixed assets to 86.8 percent (see Figure 11). In tandem, the proportion of urban residents within the overall population rose to 51.3 percent, continuing the urbanization drive commenced under Jiang (NBS 2014, tables 3-1, 5-7, 10-1).

Much like the administration's efforts to address socioeconomic issues, measures to promote the development of innovative capacity and realize the transition toward an intensive pattern of growth were shaped by a preoccupation with the development of domestic demand. For most of the post-Mao era, the state had relied on technological transformation (i.e. the purchase of turnkey installations) and a quid pro quo arrangement whereby foreign enterprises'

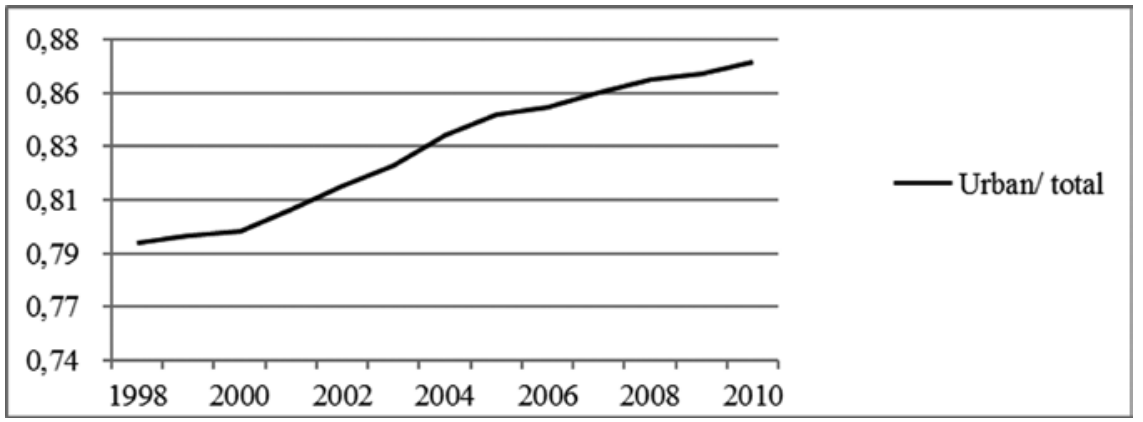

FIGURE 11 Urban investment in fixed assets as share of total, 1998-2010. SOURCE: NBS (2014, TABLE 5-2).

236 Including forestry and irrigation.

237 In the Eleventh Five Year Plan period (2006-2010) the average real growth in rural incomes was 12.32, compared to 7.53 in the preceding Five Year Plan period. See also Figure 12. 
access to Chinese markets was made contingent on the supply of advanced production technology. By contrast, the novel strategy, expounded in the "Medium and Long-Term Plan for the Development of Science and Technology," focused on the expansion of consumption and investment in domestic technology. The plan defined 16 national objectives (keji zhongda zhuanxiang). ${ }^{238}$ Excluding items within or related to the military sphere, new foci emphasized areas of biological, information and communication, and energy technology, which were believed to provide opportunities for technological leapfrogging. Central investment in these projects totaled 619.7 billion yuan in the 11th Five Year Plan period (Wen 2006-2010). Centrally coordinated initiatives were complemented with local policies. In the wake of the promulgation of the longterm plan, government issued its "Measures on Management of the Approval of Indigenous Innovation Products." Subsequently, procurement catalogues extending preferential conditions for domestic manufacturers in government procurement tenders were developed at both national and local levels (Lundvall et al. 2009). By way of these procurement policies, the state sought to leverage domestic demand in order to develop scale economies within hightech industry and promote the creation of de facto international technological standards. The outcomes of this strategy have been equivocal. ${ }^{239}$ However, like efforts to establish a new socialist countryside, the initiative to develop China's high-tech industries has been crucial in redirecting investment from traditional heavy industry and creating new sources of demand.

238 Three of these are classified defense-related projects. The other 13 are: (1) core computer components, high capacity processors and basic software; (2) integrated circuits; (3) wireless broadband communication; (4) numerical controlled machine tools; (5) oil and gas exploitation; (6) large-scale nuclear power plants; (7) water and waste treatment; (8) genetic modification; (9) pharmaceuticals; (10) contagious disease prevention; (11) large aircraft; (12) high resolution earth observation systems; and (13) manned space travel and lunar exploration. Available online at: <http://www.most.gov.cn/kjgh/ kjghzcq/>.

239 From a commercial perspective, China's rapidly growing share of the global photovoltaic market is particularly noteworthy. The development of scale economies realized by nurturing domestic demand has been instrumental to the success (Liu and Goldstein 2013). On the other hand, the development of China's proprietary fourth-generation cellular communication standard, TD-LTE - while technologically impressive-has come at the expense of considerable losses, owing to large-scale infrastructural investment and slow consumer response (Vialle, Song and Zhang 2012). 
TABLE 10 Share of industrial investment in fixed assets by sector, 2003-2010 (\%)

\begin{tabular}{lccc}
\hline Industry & $\mathbf{2 0 0 3}$ & $\mathbf{2 0 0 6}$ & $\mathbf{2 0 1 0}$ \\
\hline Communications, computing & & & \\
General purpose machinery & N/A & 6.4 & 5.2 \\
Electrical machinery, equipment & $\mathrm{N} / \mathrm{A}$ & 6.0 & $7 \cdot 3$ \\
Special purpose machinery & $\mathrm{N} / \mathrm{A}$ & $\mathrm{N} / \mathrm{A}$ & 6.7 \\
$\quad$ High-tech (total) & $\mathbf{9 . 3}$ & $\mathbf{1 6 . 6}$ & $\mathbf{2 4 . 8}$ \\
Chemical materials, products & 8.7 & 8.7 & 9.2 \\
Non-metallic mineral products & 7.0 & 7.0 & 10.1 \\
Transport equipment & 5.2 & 7.5 & 8.8 \\
Non-ferrous metals & 5.1 & $\mathrm{~N} / \mathrm{A}^{*}$ & $\mathrm{~N} / \mathrm{A}$ \\
Textile & 4.9 & 4.8 & $\mathrm{~N} / \mathrm{A}$ \\
Medicine & 4.4 & $\mathrm{~N} / \mathrm{A}$ & $\mathrm{N} / \mathrm{A}$ \\
Food processing & 4.1 & 4.5 & 4.9 \\
Metal products & $\mathrm{N} / \mathrm{A}$ & $\mathrm{N} / \mathrm{A}$ & 4.9 \\
Other & 37.5 & 41.2 & 37.3
\end{tabular}

* For high tech, these categories did not exist up until the year where their figures are added to the table. For regular industry, categories are left blank when they no longer make up part of the largest investment destinations.

SOURCES: CALCULATED BY AUTHOR FROM NBS (2004, TABLE 6-9; 2007, TABLE 6-13; 2011, 5-14).

\section{Economic Development under the 11th Five Year Plan (2006-2010)}

Although the ostensible focus of the discourse of scientific development was on issues of socioeconomic divergence and long-term economic sustainability and competitiveness, both the discourse on scientific development and concomitant programs geared toward regional and rural development and the nurturing of indigenous innovative capacity were in fact continuations of policies set in motion under Hu's predecessor. Thus, the distinctive quality of economic regulation from 2003 onward resides in the manner it appropriated the principle of readjustment to address the more mundane problem of overaccumulation. In the face of decelerating growth and the limited efficacy of traditional state investment, policy under $\mathrm{Hu}$ and Wen focused on developing domestic demand and the diversification of investment. The implications of the changing character of instruments implemented to promote domestic demand can be inferred from aggregate economic development. As shown 
in Figure 12, the traditional strategy of increasing investment in industry and urban areas pursued in the latter years of the 199os failed to realize a significant acceleration of the growth of household consumption expenditure (HCE). Limited increases in the domestic consumption was due predominantly to the slow growth of rural incomes. With the step-wise abolition of agricultural taxes under $\mathrm{Hu}$ and Wen, rural incomes did increase rapidly, causing a more even rate of growth in cities and countryside. Household consumption rose in tandem, even surpassing the rate of growth of GDP in 2007. The acceleration of the growth of household consumption was temporarily reversed due to economic recession precipitated by the global financial crisis in 2008. However, in the years following, the general trend toward higher consumption expendituredriven in large part by 4 trillion yuan in central stimulus - continued. ${ }^{240}$

In spite of the higher growth rate of household consumption, the reliance of the Chinese economy on additions to the stock of fixed capital has increased. The development of new urban hubs, rural infrastructure and technologyintensive industries provided novel outlets for capital, allowing for the continuation of rapid GFCF without creating additional duplicative investment and contributing to the problem of excessive capacity. These forays into heretofore unexploited regions or industries translated into rapid growth. China's GDP increased by an annual average of 10.9 percent between 2003 and 2012

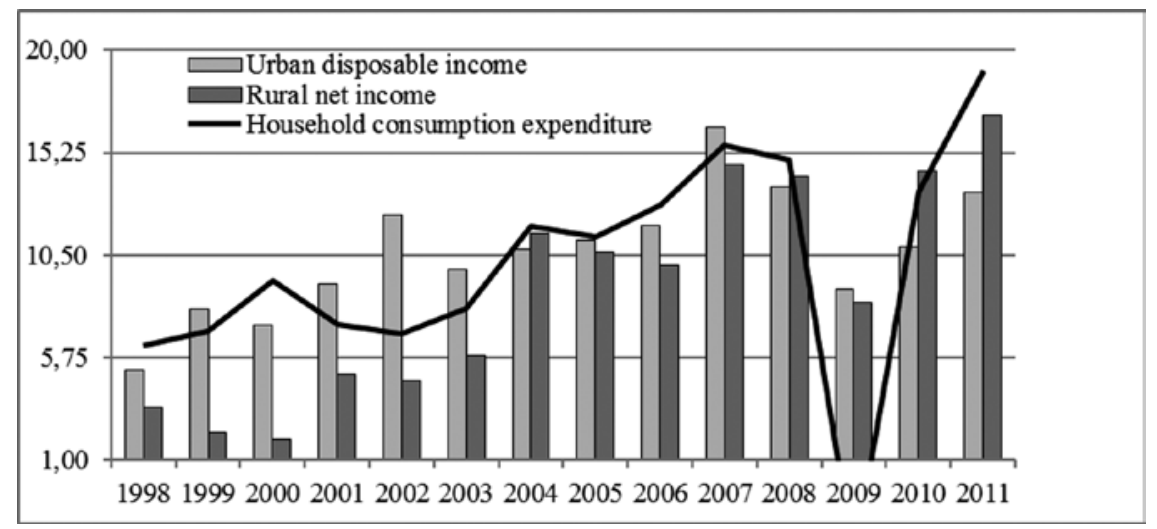

FIGURE 12 Year-on-year percentage growth of household consumption and incomes under three diverging fiscal policies, 1998-2011.

SOURCES: NBS (2009, TABLES 1-10, 1-21, 1-23; 2013, TABLES 2-19, 10-1, 11-2).

240 Of this 4 trillion, 43.7 percent was expended on subsidies to household consumption, such as government-subsidized housing, rural health care and education and other public services, while the remainder was invested in the development of indigenous innovation, industrial restructuring and environmental measures (15.3 percent), major infrastructural projects (23.6 percent) and disaster relief 14.8 percent. See Wen (2010, ch. 1). 
(NBS 2012). Even as the financial crisis caused global stagnation in 2008 and 2009, Chinese economic growth, bolstered by increased government spending, reached 9.6 and 9.2 percent (see Table 11). In the same period, GFCF as a share of GDP steadily grew, from 38.5 to 44.5 percent, far surpassing the rates achieved during China's Great Leap Forward (Table 12). ${ }^{241}$ Even after the turn of the century, when central government seemed resolved to decrease its dependence on investment-driven development in favor of a model stressing socioeconomic development and industrial innovation, the expansion of fixed assets continued to accelerate as this new resolve coincided with an emphasis on sustaining economic development by promoting the agglomeration of supply and demand. Although sectoral adjustment, urbanization and investment in rural infrastructure did fuel rapid economic growth, policies intensified reliance on accumulation, rather than effectuating a transition toward a more balanced trajectory of development.

TABLE 11 Economic growth rates in China, 2002-2015 (\%)

\begin{tabular}{lc}
\hline Year & Growth rate \\
\hline 2002 & $9 \cdot 1$ \\
2003 & 10.0 \\
2004 & 10.1 \\
2005 & $11 \cdot 3$ \\
2006 & $12 \cdot 7$ \\
2007 & 14.2 \\
2008 & $9 \cdot 6$ \\
2009 & 9.2 \\
2010 & 10.6 \\
2011 & $9 \cdot 5$ \\
2012 & $7 \cdot 7$ \\
2013 & $7 \cdot 7$ \\
2014 & $7 \cdot 3$ \\
2015 & 6.7 \\
\hline
\end{tabular}

SOURCES: ZHONGGUO TONGJI NIANJIAN (2015, P. 64); NBS (2016).

241 In estimating gross capital formation, we do not include inventory accumulation. During the 1980 s inventories accounted for, on average, 7 percent of GDP. They were essentially abolished during the SOE reforms in the late 1990 s and have, since 2000, only averaged 2 percent of GDP. 
The 2008 financial crisis aggravated the problems. Faced with the risk of an economic slowdown caused by the global financial crisis, the government decided to implement an enormous stimulus package of 4 trillion Rм в (US\$616). Most of it was earmarked for infrastructure development (Brødsgaard et al. 2016). Since the infrastructure-related sectors (including water and environment, electricity, gas, transport) in China are dominated by soes, the stimulus package benefited large soes. In contrast, the largely private manufacturing sector was, except in the case of a few industries, excluded from the stimulus package. Statistics show that due to the stimulus package the fixed investment growth rate of soE fixed asset investment surged to a record high of 35 percent, while fixed asset investment in infrastructure-related sectors alone grew by 43 percent. In 2009 investments reached a share of 44.1 percent of GDPthe highest share in the six decades of China's economic development. In 2010 the share increased even further to almost 44.6 percent (see Table 12).

TABLE 12 Chinese capital formation 2000-2015 (share of GDP (\%))

\begin{tabular}{llll}
\hline Year & $\begin{array}{l}\text { Gross capital } \\
\text { investment }\end{array}$ & $\begin{array}{l}\text { Fixed capital } \\
\text { investment }\end{array}$ & Inventory \\
\hline 2000 & $33 \cdot 9$ & 32.9 & 1.0 \\
\hline 2001 & $35 \cdot 9$ & 33.8 & 2.1 \\
\hline 2002 & 36.5 & $35 \cdot 4$ & 1.1 \\
\hline 2003 & 39.9 & 38.5 & 1.4 \\
\hline 2004 & 42.2 & 39.9 & 2.3 \\
2005 & 40.5 & $39 \cdot 5$ & 0.9 \\
\hline 2006 & 40.0 & 38.9 & 1.2 \\
\hline 2007 & 40.7 & 38.1 & 2.6 \\
\hline 2008 & 42.6 & 39.4 & 3.2 \\
\hline 2009 & $45 \cdot 7$ & 44.1 & 1.6 \\
\hline 2010 & 47.2 & 44.6 & 2.7 \\
\hline 2011 & $47 \cdot 3$ & 44.5 & 2.8 \\
\hline 2012 & 46.5 & 44.5 & 2.0 \\
\hline 2013 & 46.5 & 44.6 & 1.9 \\
\hline 2014 & 45.9 & 43.9 & 2.0 \\
\hline 2015 & 44.1 & 42.5 & 1.6 \\
\hline
\end{tabular}

SOURCE: ZHONGGUO TONGJI ZHAIYAO (2016, P. 37). 
Efforts to deal with China's dualistic economic structure (i.e. spatial economic disparity) did seem to have some effect. After 2003, the rate of divergence between rural and urban incomes slowed down markedly, and limited convergence even occurred from 2009 onward. However, in 2011, the last year of the $\mathrm{Hu}$ and Wen administration, average rural incomes still only amounted to a third of average urban incomes (NBS 2013, table 11-1). Whereas rural tax reform and the expansion of investment in China's countryside and inland regions did diminish inherent urban bias, institutional constraints on the mobility of agricultural workforce continued to undermine the emancipation of the rural population. ${ }^{242}$ Nevertheless, construction within China's rural and inland regions created new demand for investment, pushing the rate of fixed capital formation ever upward.

In a similar vein, the development of indigenous innovative capacity has been characterized by a significant absolute increase of industrial innovation related activity, but overall progress has been limited. Aggregate enterprise expenditure on research and development $(\mathrm{R} \& \mathrm{D})$ surpassed that on technological transformation, ${ }^{243}$ suggesting reduced reliance on extant technology in favor of autonomous development. However, an examination of patent grant data suggests that the vast majority of these activities concern incremental developments of extant products or technology, or changes in design. ${ }^{244}$ Thus, it appears that efforts to develop China's high-tech industries have been more instrumental in increasing production, rather than truly nurturing indigenous capacity for innovation.

\section{Conclusion}

Although fiscal recentralization under Jiang had curbed indiscriminate local investment in industry and thereby attenuated systemic inflationary tendencies, the long-term prospects of the economy were undermined by the

\footnotetext{
242 These constraints will be discussed in the subsequent section.

243 In 2003 total expenditure of large and medium-sized enterprise on technological transformation and R\&D stood at 189.6 and 72.1 billion yuan respectively. By 2010, expenditure on R\&D increased to 401.5, surpassing total expenditure on technological transformation by some 37.6 billion yuan (NBS 2011, table 2-1.3).

244 In 2010, of total patents granted to Chinese enterprise, 46.2 percent were utility patents (i.e. incremental improvements of extant products or processes), design patents accounted for another 43 percent. Only 10.8 percent of patents granted were classified as innovations (State Intellectual Property Office of the PRC, http://www.sipo.gov.cn).
} 
persistent reverberations of the strategy of accelerated accumulation. The unrelenting focus on the expansion of heavy industry had led to the neglect of agricultural development. Moreover, due to concentration of industry in coastal and urban areas, uneven sectoral development was reflected in China's geographical composition, resulting in a distinctively dichotomous economic structure. The scientific development concept, emphasizing the development of China's rural and interior regions, suggested a departure from policies emphasizing the expansion of urban industry. These new measures were widely hailed by both domestic and foreign observers as a major advance toward more equitable sectoral relations (Day 2013). Concurrently, leadership sought to bolster overall productivity and international competitiveness by redirecting investment from capital- to technology-intensive industry. However, enthusiasm for the ostensible shift in economic regulation was not ubiquitous. While most of China's economists approved of the objectives of more equitable development in principle, ${ }^{245}$ reform-minded economists were skeptical of the state's interventionist orientation. In their opinion, the success of the transition toward more equitable and efficient economic growth depended ultimately on the continuation of institutional reforms (Zhang 2005; Fan 2008; Li 2008).

At first glance, the introduction of scientific development did appear to be accompanied by certain significant institutional advances. After years of contention between the Party's conservative and progressive factions, a Property Law was drafted in 2004. Yet further controversy delayed adoption of the law for another three years. The law guaranteed private rights to income, real estate and capital, as well as savings and investments. ${ }^{246}$ Although the official recognition of private property was significant from an ideological standpoint, it had little bearing on the actual operation of the economy. Rather than truly prompting institutional change, the law amounted to a de jure acknowledgment of individual economic rights that had essentially been uncontested since the constitutional recognition of the private economy. At the same time, the state had maintained its control over financial markets and key economic sectors, perpetuating the unequal access to resources within the public and private industry. Likewise, adjustments to the household registration system

245 Fan Gang, a former researcher of the Chinese Academy of Social Science and cofounder of the Unirule Institute, provides a notable exception. In an article written with Xiaolu Wang, Fan argues that initial socioeconomic divergence was a natural concomitant of the transition toward industrialization. A premature preoccupation with more egalitarian development would stymie economic growth and inevitably obstruct China's convergence with fully modernized Western economies (2004).

246 "Zhonghua renmin gongheguo wuquanfa" (2007, articles 64-5). 
reflected the reality of loss of central control over migratory movement, rather than the emancipation of rural workers. The "Decision on Certain Major Issues regarding the Promotion of Rural Reforms" of 2008 called for the:

[U]nification of rural and urban societal management, advancement of reform of the household registration system, broadening of the conditions for settlement in small and medium sized cities, and the orderly transformation of rural to urban registration status of persons who have stable employment and residence in towns and city. ${ }^{247}$

In order to facilitate urban settlement and promote the development of scaleefficient farming, the Decision also sanctioned the transfer of usage rights of farmland. Nevertheless, the flow of labor from the countryside to the city continued to be impeded. ${ }^{248}$ Reforms did not extend to taxation, employment and welfare policies (administered by different administrative entities), so that divergences between the rights of registered urbanites and rural migrants persisted (Hu 2009). Moreover, ownership of rural land remained invested within the collective, diluting individual farmers' incentives to engage in efficiencyenhancing investments (Yu 2010).

By the end of the 11th Five Year Plan period, even central leadership had to concede that measures introduced under the leadership of $\mathrm{Hu}$ and Wen had been inefficacious:

[We] must clearly observe that the problems of unbalanced, nonharmonious and unsustainable development are still obvious; primarily, resource-related and environmental constraints on economic growth have intensified, the relationship between investment and consumption is unbalanced, income disparity is comparatively large, the capacity for innovation is not strong, industrial structure remains irrational, the agricultural basis is still weak, the development of cities and countryside and regions is unequal, employment pressure coexists with structural

247 "Tuijin nongcun gaige fazhan ruogan zhongda wenti de jueding" (2008). Experimentation had commenced in 2005, when 13 provinces, autonomous regions and municipalities had proceeded with adjustments to the system of administrative segregation of rural and urban residents.

248 Large cities, fearing the destabilizing socioeconomic consequences of the abrogation of household registration, were loath to engage in reforms. Furthermore, in affluent regions conditions for eligibility of the transformation from rural to urban status have remained prohibitively high for the vast majority of rural residents (Kam and Buckingham 2008). 
contradictions, social contradictions have clearly increased, and there are still many institutional obstacles that impede scientific development. ${ }^{249}$

Nevertheless, the 12th Five Year Plan, issued in May 2011, continued to adhere to a strategy of promoting domestic demand and sectoral restructuring by way of intensified state coordination. The economic paradigm that developed in the wake of the structural reforms of 1998 and was consolidated under $\mathrm{Hu}$-with its focus on nurturing new urban areas and industry and deferring consumption for a promise of greater future dividends-echoes the logic of accelerated accumulation, which provided the template for economic development in the planned economy.

249 "Guanyu zhiding guominjingji he shehui fazhan di shier ge wu nian guihua de jianyi" (2010, ch. 1). 